\title{
Peripheral immune cell markers in children with recurrent respiratory infections in the absence of primary immunodeficiency
}

\author{
ADRIANA NARCISA MUNTEANU ${ }^{1,2}$, MIHAELA SURCEL ${ }^{1,2}$, RADU-IONUȚ HUICĂ $\breve{~}^{3}$, \\ GHEORGHIT,A ISVORANU ${ }^{4}$, CAROLINA CONSTANTIN ${ }^{1,5}$, IOANA RUXANDRA PÎRVU ${ }^{1}$, \\ CARMEN CHIFIRIUC $^{2}$, CORIOLAN ULMEANU ${ }^{6}$, CORNEL URSACIUC ${ }^{1}$ and MONICA NEAGU ${ }^{1,2,5}$
}

${ }^{1}$ Immunobiology Laboratory, 'Victor Babes' National Institute of Pathology, 050096 Bucharest; ${ }^{2}$ Doctoral School of Biology, Faculty of Biology, University of Bucharest, 050095 Bucharest; ${ }^{3}$ Division of Cellular and Molecular Biology and Histology,

'Carol Davila' University of Pharmacy and Medicine, 050474 Bucharest; ${ }^{4}$ Animal Husbandry, 'Victor Babes' National Institute of Pathology, 050096 Bucharest; ${ }^{5}$ Department of Pathology, Colentina University Hospital, 020125 Bucharest;

${ }^{6}$ Department of Toxicology, 'Grigore Alexandrescu' Children's Emergency Clinical Hospital, 011743 Bucharest, Romania

Received May 21, 2019; Accepted June 24, 2019

DOI: $10.3892 / \mathrm{etm} .2019 .7714$

\begin{abstract}
The immune system of a child has a degree of immaturity that is maintained until 6-7 years of age. Immaturity may be due to age-related functional disorders in the immune response. A healthy child can contract a series of infections which contribute to the maturation of the immune system during the pre-pubertal period. If repeated infections with prolonged or severe complications occur during childhood, the presence of an immunodeficiency should then be considered. Much more frequent than primary immunodeficiency are recurrent infections (frequently involving the upper respiratory tract), which are less severe and occur under the conditions of an immune system with no apparent major defects. A child can present with 4 to 8 episodes of respiratory infections within a year, during the first 5 years of its life. The average duration of infection is 8 days and up to 2 weeks; if the child presents with 3 episodes of acute infections over a period of 6 months,
\end{abstract}

Correspondence to: Dr Monica Neagu, Immunobiology Laboratory, 'Victor Babes' National Institute of Pathology, 99-101 Splaiul Independentei, 050096 Bucharest, Romania

E-mail: neagu.monica@gmail.com

Abbreviations: APC, allophycocyanin; CD, cluster of differentiation; FACS, fluorescence-activated cell sorting; FITC, fluorescein isothiocyanate; FID, functional immunodeficiency; ID, immunodeficiency; K2-EDTA, kalium 2 ethylenediaminetetraacetate; $\mathrm{NK}$, natural killer cells; $\mathrm{PE}$, phycoerythrin; $\mathrm{PE} / \mathrm{Cy}$, phycoerythrin complex with cyanine; PerCP/Cy, peridinin chlorophyll protein complex with cyanine; PB, peripheral blood; PID, primary immunodeficiency; RPMI, Roswell Park Memorial Institute; RRI, respiratory recurrent infections; RSV, respiratory syncytial virus; $\mathrm{SD}$, standard deviation

Key words: recurrent respiratory infections, memory B cells, double-negative T cells the respiratory infections are then considered recurrent. The aim of this study was to identify the immunological changes or deviations that cause this clinical syndrome in children. For this purpose, 30 children with recurrent respiratory infections and 10 healthy children were included. Immunoglobulin levels were examined and immunophenotyping was performed. We found that the serum immunoglobulin levels were in the normal range in $70 \%$ of the children. On the contrary, our data revealed changes in peripheral cell populations, the most important being the decrease in the T-cluster of differentiation (CD) $8^{+}$and total $\mathrm{B}$ cell percentages and the increase in the number of memory B cells. The data obtained herein indicated that the decrease in the number of total $\mathrm{B}$ cells was mainly due to the decrease in the number of naive $\operatorname{IgD}^{+} \mathrm{B}$ cells. On the whole, the findings of this study indicate that recurrent respiratory infections may be associated with an altered cellular immune response. In such situations, the investigation of immunological parameters, such as $\mathrm{T}$ and $\mathrm{B}$ cell subtypes could complete the clinical diagnosis and guide the treatment strategy, thus increasing the quality of life of patients.

\section{Introduction}

The immune system of a child has a degree of immaturity that is maintained from the time the child is a new-born until 6-7 years of age. This immaturity may be due to age-related functional disorders in the immune response (1). Therefore, the child's immune response is considered 'hypo-inflammatory' (2). Throughout this period, a healthy child can contract a series of infections, which contribute to the strengthening of the immune system, expanding immunological memory and increasing the immune response. These conditions contribute to the maturation of the immune system during the pre-pubertal period. If repeated or prolonged infections with significant clinical expression (pulmonary and cutaneous) and possible complications, occur during childhood, the presence of a humoral or cellular immunodeficiency (ID) should then be considered (3). 
Generally, IDs can be classified in quantitative ID, when the components of the immune system are numerically diminished, or functional ID (FID) when, although cellular elements are numerical within normal limits, cellular activation mechanisms are disrupted, clonal expansion is defective, and/or intercellular cooperation and effector mechanisms are deficient. The quantitative ID (primary or secondary) consists of diminishing the immune response efficiency caused by the absence of any major components of the immune system: Lymphocytes, phagocytes, immunoglobulins, and complement system elements (4). The consequence of ID is the impossibility of providing a full defence of the organism against infectious agents.

Much more frequent than primary ID (PID) are recurrent infections (RIs). These are less severe, occurring in the absence of PID, under the conditions of an immune system with no apparent major defects (5). This requires finding the causes that may produce functional imbalances in the immune system or conditions that induce a secondary or acquired form of ID. Sometimes, a FID may be suspected based on minor symptoms related to the respiratory system (oro-pharyngeal) or the appearance of the skin symptoms (allergic syndromes, minor infections, and mycosis). RIs are the most frequent expression of FID, and a persistent and repeated infectious syndrome can generate changes or delays in the overall development of the child. The causes of this pathology are multiple, being congenital or acquired, but also at the local or general level.

Immune deficiencies are considered as underlying conditions predisposing to RIs (6). Taking into account that a child's immune system is still developing until the age of 12-14 years, and that infections can halt this development, it is crucial to identify the weak links of anti-infective defence in children and, if possible, to correct them. Sometimes, the maturation of the immune system corrects some functional deficiencies; however, if they are not corrected spontaneously, a diagnosis and an appropriate therapy are required.

Respiratory RIs (RRIs) are more common in children and frequently involve the upper respiratory tract (7). The number of infections per year also depends on the exposure to pathogens, living standards, day-care attendance, complications, the geographical area and second-hand smoke (8). According to data of the World Health Organization (WHO), a child can present with 4 to 8 episodes of RIs within a year, during the first 5 years of its life (9). The average duration of infection is 8 days and up to 2 weeks; if a child presents with 3 episodes of acute infections over a period of 6 months, the respiratory infections are then considered recurrent (6).

As RRIs (in the absence of PID) may be associated with an altered cellular immune response, we it can be considered that in such situations, an extended immunophenotyping with the investigation of immunological parameters, such as $\mathrm{T}$ and $\mathrm{B}$ cell subtypes, is useful.

In this study, we investigated a group of children with RRIs (in the absence of PID) positive for respiratory syncytial virus (RSV) to observe the immunological changes that could lead to this clinical syndrome. The serum levels of immunoglobulins (IgGs, IgA, IgM) were examined and lymphocyte immunophenotyping was performed. The currently investigated T, B and natural killer (NK) lymphocyte populations and subpopulations were completed with some subsets not usually quantified: T-double-negative (T-DN) cells [cluster of differentiation (CD) $\left.45^{+} \mathrm{CD}^{+}{ }^{+} \mathrm{CD}^{-} \mathrm{d}^{-} \mathrm{CD} 4^{-} \mathrm{CD} 8^{-}\right]$, mature/naive $\mathrm{B}$ cells $\left(\mathrm{CD}^{2} 5^{+} \mathrm{CD} 19^{+} \mathrm{CD} 20^{+} \mathrm{CD} 27^{-}, \mathrm{IgD}^{+}\right)$, memory B cells $\left(\mathrm{CD} 45^{+} \mathrm{CD} 19^{+} \mathrm{CD} 20^{+} \mathrm{CD} 27^{+}\right)$, switched memory B cells $\operatorname{IgD}^{-} \mathrm{IgM}^{-}$, non-switched memory $\mathrm{B}$ cells $\operatorname{IgM} / \mathrm{IgD}^{+}$, non-switched $\operatorname{IgD}^{+} \operatorname{IgM}^{+}$memory B cells, plasmablasts/plasma cells $\left(\mathrm{CD} 45^{+} \mathrm{CD} 19^{+} \mathrm{CD} 10^{-\mathrm{CD}} 27^{+} \mathrm{CD} 38^{\text {bright }}\right)$, NKT cells $\left(\mathrm{CD} 45^{+} \mathrm{CD}^{+} \mathrm{CD} 16^{+} \mathrm{CD} 56^{+} \mathrm{CD} 1 \mathrm{~d}^{+}\right)$. This comprehensive cellular investigation could complete the clinical diagnosis and may further guide treatment.

\section{Materials and methods}

Patients. A group of 48 children diagnosed with RRIs, having at least 6 episodes of respiratory infections during a year were considered. The diagnosis was established at 'Grigore Alexandrescu' Children's Emergency Clinical Hospital in Bucharest, Romania based on a clinical evaluation and the patient's history. The target group selection was made depending on the presence of IgG antibodies against RSV in serum (ELISA quantitative determination of serum $\mathrm{IgG}$ antibodies against RSV-IBL International $\mathrm{GmbH}$ ). At the time of testing, the children had surpassed the acute respiratory episode and no therapy was administered at least 2 weeks before actual testing.

In order to evaluate the peripheral blood (PB) lymphocytes, 2 groups of children were considered: i) the RRI group, which included 30 children (19 boys and 11 girls, aged 1-7 years) presenting a positive titre of anti-RSV IgG; and ii) the control group, which included 10 healthy children, with a normal nutritional status, with no fever, no history of the use of medications, no immunizations during the past 4 weeks, and no evidence of infectious diseases and haematological or immunological disorders. Subjects with atopic disorders were excluded. For all patients and the control group, an informed consent was signed from each subject's legally authorized representative. The study was approved by the Ethics Committee from Victor Babes National Institute (no. 17/17.05.2016). Subjects were recruited regardless of race or ethnic background, and their home status was from a medium to high family income.

Blood sampling. Peripheral blood samples from the RRI and control group were collected by venipuncture during the morning hours in K2-EDTA coated tubes and in blood clot activator tubes (Vacutest Kima). Blood collection was carried out at the 'Grigore Alexandrescu' Children's Emergency Clinical Hospital. Serum samples, separated by centrifugation (1,500 x g, $10 \mathrm{~min}$, room temperature) within $4 \mathrm{~h}$ of blood collection, were used for quantitative determination of immunoglobulins. Peripheral blood samples collected in K2-EDTA coated tubes were stained for flow cytometry as described below on the day of blood collection.

Nephelometry. Serum levels of immunoglobulins were determined by nephelometry (Minineph). The determination of the immunoglobulin concentration by nephelometry involved an antigen-antibody reaction in order to form insoluble immune complexes. Briefly, the principle of the test is that when a luminous ray is passing through the formed suspension, 
the dispersed fraction can be measured by a photodiode. The degree of light scattering is directly proportional to the concentration of the protein in the sample. Concentrations are automatically calculated by reference to a calibration curve stored in the device memory. As quality control, we used high and low controls provided with the kits. The levels of IgG (Minineph Human IgG kit), IgA (Minineph Human IgA kit) and IgM (Minineph Human IgM kit) were quantified for all the participants included in this study.

Flow cytometric analysis [fluorescence-activated cell sorting (FACs) analysis]. The immunophenotyping of PB lymphocytes was performed by flow cytometry with an 8-color system setup, based on the expression of surface markers. As negative controls, we used unlabelled cells and the compensation of a fluorescence signal overlapping was performed (Anti-Mouse Ig, $\kappa /$ Negative Control (FBS) Compensation Particles Set, BD Biosciences). Data acquisition and analysis were performed on a BD FACSCanto II cytometer with BD FACSDiva v.6.1 software (BD Biosciences). Cytometer performances were checked properly using CST beads (BD Cytometer Setup \& Tracking Beads kit; BD Biosciences).

EDTA-anticoagulated whole blood samples were split into 2 different custom panels: The T- and NK-panel, in order to identify T-cell subsets and NK cells, respectively B-panel, for B-cell subsets. For each panel, $100 \mu 1$ whole blood was incubated with specific monoclonal antibodies for the targeted cell populations, for $20 \mathrm{~min}$ at room temperature in the dark. Surface staining was followed by red blood cell lysis with BD FACS Lysing Solution (BD Biosciences) for $10 \mathrm{~min}$ at room temperature in the dark and spun down for $5 \mathrm{~min}$ at $350 \mathrm{x} \mathrm{g}$ and room temperature. The cells were washed twice with Cell Staining Buffer (BioLegend) and analysed by flow cytometry.

For the T- and NK-panel, the following monoclonal antibodies conjugated with fluorochromes were used: mouse anti-human CD3-FITC (isotype IgG1, clone UCHT1, cat. no. 1F-514-T025, $20 \mu 1 / 100 \mu 1$ whole blood), mouse anti-human CD16-PE (isotype IgG1, clone 3G8, cat. no. 1P-646-T025, $20 \mu 1 / 100 \mu 1$ whole blood), mouse anti-human CD56-PE (isotype IgG2a, clone LT56, cat. no. 1P-789-T025, $10 \mu \mathrm{l} / 100 \mu \mathrm{l}$ whole blood), mouse anti-human CD4-PE-Cy7 (isotype IgG1, clone MEM-241, cat. no. T7-359-T025, $4 \mu \mathrm{l} / 100 \mu \mathrm{l}$ whole blood) and mouse anti-human CD8- allophycocyanin (APC)-Cy7 (isotype IgG2a, clone MEM-31, cat. no. T4-207-T025, $4 \mu \mathrm{l} / 100 \mu 1$ whole blood) (Exbio), mouse anti-human CD45-PerCP-Cy5.5 (isotype IgG1, clone HI30, cat. no. 564106, $5 \mu 1 / 100 \mu 1$ whole blood, BD Pharmingen-BD Biosciences) and mouse anti-human CD1d-Brilliant Violet 510 (isotype $\operatorname{IgG} 2 \mathrm{~b} \kappa$, clone 51.1, cat. no. 350314, $5 \mu \mathrm{l} / 100 \mu \mathrm{l}$ whole blood, BioLegend). The defined populations were as follows: T-CD3 ${ }^{+}$lymphocytes $\left(\mathrm{CD} 45^{+} \mathrm{CD} 3^{+}\right)$and $\mathrm{T}-\mathrm{CD} 4^{+}$ $\left(\mathrm{CD} 45^{+} \mathrm{CD}^{+} \mathrm{CD}^{+}\right), \mathrm{T}-\mathrm{CD} 8^{+}\left(\mathrm{CD} 45^{+} \mathrm{CD} 3^{+} \mathrm{CD} 8^{+}\right)$and T-double negative (T-DN; $\left.\mathrm{CD}^{-} 5^{+} \mathrm{CD} 3^{+} \mathrm{CD} 1 \mathrm{~d}^{-} \mathrm{CD} 4{ }^{-} \mathrm{CD} 8^{-}\right)$ subsets, NK cells $\left(\mathrm{CD} 45^{+} \mathrm{CD} 3{ }^{-} \mathrm{CD} 16^{+} \mathrm{CD} 56^{+}\right)$and $\mathrm{NKT}$ cells $\left(\mathrm{CD}^{+} 5^{+} \mathrm{CD} 3{ }^{+} \mathrm{CD} 16^{+} \mathrm{CD} 56^{+} \mathrm{CD} 1 \mathrm{~d}^{+}\right)$.

For the B-panel, the following monoclonal antibodies conjugated with fluorochromes were used: Mouse anti-human IgD-FITC (isotype IgG2b $\kappa$, clone IA6-2, cat. no. 348205 , $5 \mu 1 / 100 \mu 1$ whole blood), mouse anti-human CD38-PE (isotype IgG1 $\kappa$, clone HIT2, cat. no. 303505, $5 \mu \mathrm{l} / 100 \mu \mathrm{l}$ whole blood), mouse anti-human CD10-PE-Cy7 (isotype IgG1 $\kappa$, clone HI10a, cat. no. 312213, $5 \mu \mathrm{l} / 100 \mu \mathrm{l}$ whole blood) and mouse anti-human CD19-PerCP-Cy5.5 (isotype IgG1 $\kappa$, clone HIB19, cat. no. 302229, $5 \mu 1 / 100 \mu$ l whole blood) (BioLegend), mouse anti-human IgM-APC (isotype IgG1, clone $\mathrm{CH} 2$, cat. no. 1A-320-C025, $10 \mu 1 / 100 \mu \mathrm{l}$ whole blood EXBIO, Praha), mouse anti-human CD20-APC-H7 (isotype IgG2b $\kappa$, clone $2 \mathrm{H} 7$, cat. no. 560734, $5 \mu \mathrm{l} / 100 \mu \mathrm{l}$ whole blood), mouse anti-human CD27-Brilliant Violet 421 (isotype $\operatorname{IgG1} \kappa$, clone M-T271, cat. no. 562514, $5 \mu \mathrm{l} / 100 \mu \mathrm{l}$ whole blood) and mouse anti-human CD45-Brilliant Violet 510 (isotype IgG1 $\kappa$, clone HI30, cat. no. 563204, $5 \mu \mathrm{l} / 100 \mu \mathrm{l}$ whole blood) (BD Biosciences). The following subpopulations of B cells were gated: $\mathrm{B}$ cells $\left(\mathrm{CD} 45^{+} \mathrm{CD} 19^{+}\right.$and $\left.\mathrm{CD} 45^{+} \mathrm{CD} 19^{+} \mathrm{CD} 20^{+}\right)$, mature/naive $\mathrm{B}$ cells $\left(\mathrm{CD} 45^{+} \mathrm{CD} 19^{+} \mathrm{CD} 20^{+} \mathrm{CD} 27^{-}, \mathrm{IgD}^{+}\right)$, memory B cells $\left(\mathrm{CD} 45^{+} \mathrm{CD} 19^{+} \mathrm{CD} 20^{+} \mathrm{CD} 27^{+}\right)$, switched memory B cells IgD-IgM- ${ }^{-}$, non-switched memory B cells $\operatorname{IgM} / \mathrm{IgD}^{+}$, non-switched $\operatorname{IgD}^{+} \operatorname{IgM}^{+}$memory B cells, plasmablasts/plasma cells $\left(\mathrm{CD} 45^{+} \mathrm{CD} 19^{+} \mathrm{CD} 10^{-} \mathrm{CD} 27^{+} \mathrm{CD} 38^{\text {bright }}\right)$.

Statistical analysis. Data were analysed using Microsoft Excel (Microsoft). The results are presented as the means \pm SD of the cell percentage. The Student's t-test (two-tailed, assuming unequal variance) was used for the statistical evaluation of the differences between the experimental groups. The threshold of significance was set at a P-value $<0.05$.

\section{Results}

Serum levels of immunoglobulins. The serum immunoglobulin values in the children with RRIs were normal in $70 \%$ of the cases; $30 \%$ of the cases exhibited a decreases or increase in the immunoglobulin levels (data not shown).

Immunophenotyping of PB lymphocytes. In order to assess the immune cell status in children with RRIs, different subtypes of circulating $\mathrm{T}$ and $\mathrm{B}$ lymphocytes were analysed by flow cytometry, using two different custom panels: The $\mathrm{T}$ and NK-panel, to identify T-cell subsets and NK cells, respectively and B-panel for B-cell subsets. The results are presented below:

i) $T$ cell subsets and NK cells. The percentages of PB T cell subsets and NK cells ( $\mathrm{T}$ cells, T-CD4 ${ }^{+}$cells, T-CD8 ${ }^{+}$cells, T-DN cells, NK cells and NKT cells) for 30 children with RRIs were compared with the data obtained from 10 healthy children (control group). The analysis of T cell subpopulations revealed a significant decrease in the T-CD8+ lymphocytes percentages $(\mathrm{P}=0.009)$ in children with RRIs $(21 \pm 5 \%$ cells as compared to $24 \pm 2 \%$ in the control group). The percentages of $\mathrm{T}_{-} \mathrm{CD}^{+}$and $\mathrm{T}-\mathrm{CD} 4^{+}$lymphocytes were similar between the patients and the control group (Fig. 1).

Most of the children with RRIs exhibited changes in the relative number of $\mathrm{T}$ lymphocytes. Thus, a significant number of children $(67 \%)$ exhibited a decrease in the numbers of T-CD8 ${ }^{+}$lymphocytes; $47 \%$ of the cases presented an increased value for $\mathrm{T}_{-} \mathrm{CD} 4^{+}$lymphocytes, and $40 \%$ of the children with RRIs presented a decreased percentage of total T-CD3 ${ }^{+}$ lymphocytes (Table I).

The $\mathrm{T}-\mathrm{CD} 4^{+} / \mathrm{T}-\mathrm{CD} 8^{+}$ratio was higher in the $\mathrm{RRI}$ group $(2 \pm 1)$ as compared to the control group $(1.5 \pm 0.2)$, and the 
Table I. Incidence of T cell subsets and NK cells deregulations in the group diagnosed with RRIs.

Incidence in the RRI group (\%)

Parameter

Decreased values $(\%)$

Increased values $(\%)$

\begin{tabular}{|c|}
\hline T cells $\left(\mathrm{CD} 45^{+} \mathrm{CD} 3^{+}\right)$ \\
\hline $\mathrm{T}_{-\mathrm{CD}} 4^{+}$cells $\left(\mathrm{CD} 45^{+} \mathrm{CD} 3^{+} \mathrm{CD} 4^{+}\right)$ \\
\hline $\mathrm{T}_{-\mathrm{CD}}{ }^{+}$cells $\left(\mathrm{CD} 45^{+} \mathrm{CD}^{+} \mathrm{CD}^{+}\right)$ \\
\hline T-DN cells $\left(\mathrm{CD}^{2} 5^{+} \mathrm{CD}^{+}{ }^{+} \mathrm{CD} 1 \mathrm{~d}^{-} \mathrm{CD} 4^{-} \mathrm{CD} 8^{-}\right)$ \\
\hline $\mathrm{T}-\mathrm{CD} 4^{+} / \mathrm{T}-\mathrm{CD} 8^{+}$ \\
\hline $\mathrm{NK}$ cells $\left(\mathrm{CD} 45^{+} \mathrm{CD} 3{ }^{-} \mathrm{CD} 16^{+} \mathrm{CD} 56^{+}\right)$ \\
\hline NKT cells $\left(\mathrm{CD} 45^{+} \mathrm{CD}^{+}{ }^{+} \mathrm{CD} 16^{+} \mathrm{CD} 56^{+} \mathrm{CD} 1 \mathrm{~d}^{+}\right)$ \\
\hline
\end{tabular}

$\begin{array}{rr}40 & 13 \\ 17 & 47 \\ 67 & 10 \\ 0 & 23 \\ 10 & 63 \\ 7 & 57 \\ 0 & 0\end{array}$

RRIs, respiratory recurrent infections.

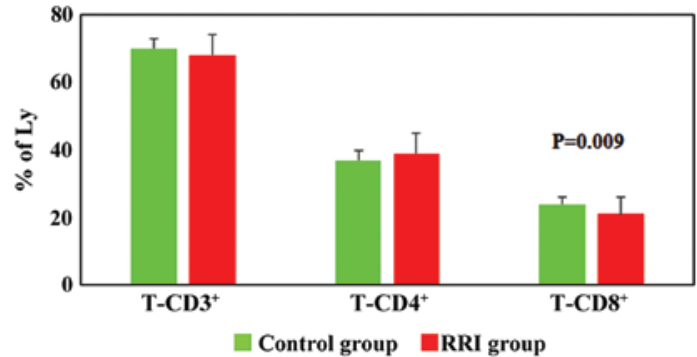

Figure 1. Distribution of T-lymphocyte subpopulations in peripheral blood. Percentage distribution of T-CD3 ${ }^{+}, \mathrm{T}-\mathrm{CD} 4^{+}$and T-CD8 $8^{+}$lymphocytes in the RRI group $(\mathrm{n}=30)(68 \pm 6,39 \pm 6$ and $21 \pm 5, \mathrm{P}=0.009)$, and in the control group $(\mathrm{n}=10)(70 \pm 3,37 \pm 3$ and $24 \pm 2)$. The results are presented as a percentage from lymphocytes (means $\pm \mathrm{SD}$ ). RRI, respiratory recurrent infection.

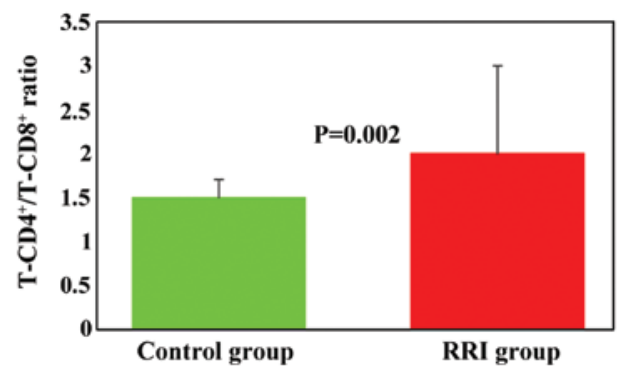

Figure 2. Distribution of the T-CD $4^{+} / \mathrm{T}-\mathrm{CD} 8^{+}$ratio in peripheral blood. Distribution of the T-CD4 $4^{+}$T-CD8 ${ }^{+}$ratio in the RRI group $(\mathrm{n}=30)(2 \pm 1$, $\mathrm{P}=0.002)$ and in the control group $(\mathrm{n}=10)(1.5 \pm 0.2)$. The results are presented as the mean values $\pm \mathrm{SD}$. RRI, respiratory recurrent infection.

differences between the experimental groups were statistically significant ( $\mathrm{P}=0.002$; Fig. 2). A significant number of children with RRIs (63\%) exhibited an increased value for the T-CD4 ${ }^{+}$T-CD8 ${ }^{+}$ratio (Table I).

The values obtained for T-DN for both experimental groups were within normal limits, only $23 \%$ of RRI children had an increased value (>10) (Fig. 3 and Table I). For all the lymphocyte subpopulations described above, the ranges obtained for the control group were similar with the normal values described in the literature (10). Only for the NK cells, the range of normal values (6-10\%) was below the values described in the literature (8-15\%). Although the NK cell values

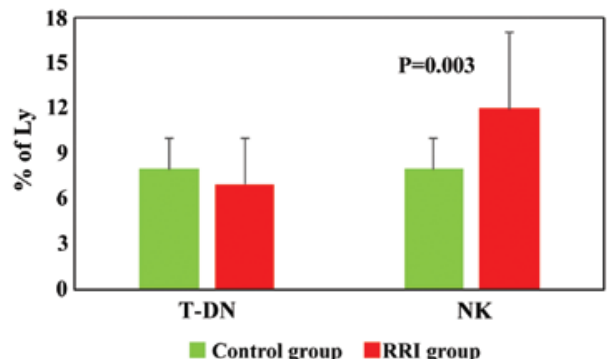

Figure 3. Distribution of T-DN lymphocytes and NK cells in peripheral blood. T-DN lymphocytes and NK cells in the RRI group $(n=30)(7 \pm 3$ and $12 \pm 5, \mathrm{P}=0.003)$ and in the control group $(\mathrm{n}=10)(8 \pm 2$ and $8 \pm 2)$. The results are presented as percentage from lymphocytes (means $\pm \mathrm{SD}$ ). RRI, respiratory recurrent infection; T-DN, T-double negative; NK, natural killer.

were significantly higher in the RRI group $(12 \pm 5, \mathrm{P}=0.003)$ as compared to the healthy children $(8 \pm 2)$, and $57 \%$ of children with RRIs exhibited increases, these values were within the normal range for NK cells (Fig. 3 and Table I) (10). NKT cell analysis (\% of lymphocytes) revealed very low values for both groups $(0.01 \pm 0.02$ for RRI group and $0.01 \pm 0.01$ for control group) (graph not shown).

In terms of overall $\mathrm{T}$ and NK circulatory populations, in Table I, the incidence of peripheral deregulations is presented in the group of children with RRIs. It can be easily seen that most of the decreased values were registered in the T-CD8 ${ }^{+}$ subpopulation, followed by the total $\mathrm{T}-\mathrm{CD} 3^{+}$population. As regards the incidence of increased values, the highest incidence was observed for the T-CD4 ${ }^{+}$subpopulation. The consequence is that the $\mathrm{T}-\mathrm{CD} 4^{+} / \mathrm{T}-\mathrm{CD} 8^{+}$ratio was increased in the majority of the children tested.

ii) B cell subsets. Peripheral blood B cell subsets (total B cells, mature/naive B cells, memory B cells, switched memory B cells IgD-IgM-', non-switched memory B cells $\operatorname{IgM} / \operatorname{IgD}^{+}$, non-switched $\operatorname{IgD}^{+} \operatorname{IgM}^{+}$memory B cells, plasmablasts/plasma cells) were evaluated for 30 children with RRIs and the obtained data were compared with the children in the control group.

The main change observed in panel B analysis was the decrease in the total B cell population percentages in most of the children with RRIs $(86 \%)$ (Table II). The mean values 
Table II. Incidence of B cell subsets deregulations in the group diagnosed with RRIs.

\begin{tabular}{lcc}
\hline Parameter & Decreased values (\%) & Increased values (\%) \\
\hline B cells $\left(\mathrm{CD} 45^{+} \mathrm{CD} 19^{+}\right.$and CD45 $\left.{ }^{+} \mathrm{CD} 19^{+} \mathrm{CD} 20^{+}\right)$ & 86 & 7 \\
Mature/naive B cells $\left(\mathrm{CD} 45^{+} \mathrm{CD} 19^{+} \mathrm{CD} 20^{+} \mathrm{CD} 27^{-} \operatorname{IgD}^{+}\right)$ & 61 & 18 \\
Memory B cells $\left(\mathrm{CD} 45^{+} \mathrm{CD} 19^{+} \mathrm{CD} 20^{+} \mathrm{CD} 27^{+}\right)$ & 21 & 50 \\
Non-switched IgD $\operatorname{IgM}^{+}$memory B cells & 14 & 43 \\
Non-switched memory B cells IgM/IgD & 18 & 39 \\
Switched memory B cells IgD-IgM & 25 & 29 \\
Plasma cells $\left(\mathrm{CD} 45^{+} \mathrm{CD} 19^{+} \mathrm{CD} 10^{-} \mathrm{CD} 27^{+} \mathrm{CD} 38^{\text {bright }}\right)$ & 0 & 7
\end{tabular}

RRIs, respiratory recurrent infections.

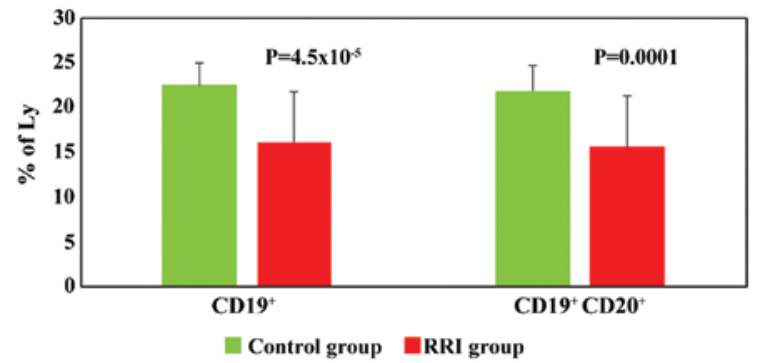

Figure 4. Distribution of total B lymphocytes $\left(\mathrm{CD} 19^{+}\right.$and $\left.\mathrm{CD} 19^{+} \mathrm{CD} 20^{+}\right)$in peripheral blood. $\mathrm{CD} 19^{+}$and $\mathrm{CD} 19^{+} \mathrm{CD} 20^{+}$in the RRI group $(\mathrm{n}=30)(16.14 \pm 6$, $\mathrm{P}=4.5 \times 10^{-5}$ and $\left.15.65 \pm 6, \mathrm{P}=0.0001\right)$ and in the control group $(\mathrm{n}=10)(22.56 \pm 2$ and $21.9 \pm 3$ ). The results are presented as a percentage from lymphocytes (means $\pm \mathrm{SD})$. RRI, respiratory recurrent infection.

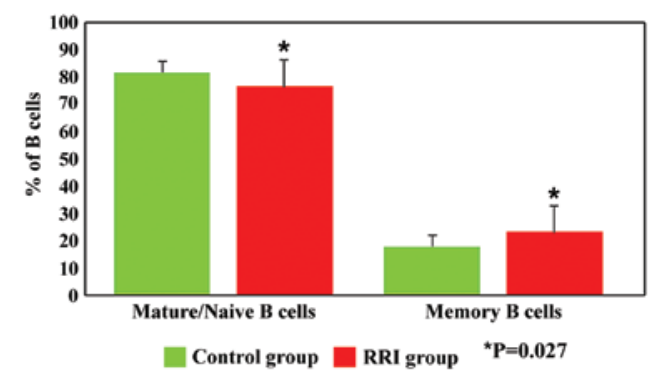

Figure 5. Distribution of mature/naive B cells and memory B cells in peripheral blood. Mature/naive B cells and memory $B$ cells in the RRI group $(n=30)$ (76.8 $\pm 10, P=0.027$ and $23.2 \pm 10, P=0.027)$ and in the control group $(n=10)$ $(81.95 \pm 4$ and $18.05 \pm 4)$. The results are presented as percentage from B cells $\left(\mathrm{CD} 19^{+} \mathrm{CD} 20^{+}\right)($means $\pm \mathrm{SD})$. RRI, respiratory recurrent infection.

of total B cells were significantly lower in the children with RRIs $\left(16.14 \pm 6, \mathrm{P}=4.5 \times 10^{-5}\right)$ as compared to the control group (22.56 \pm 2$)$ (Fig. 4).

The PB total B lymphocytes were divided into 2 subsets based on CD27 expression: Mature/naive B cells (CD27 $)$ and memory B cells $\left(\mathrm{CD} 27^{+}\right)$. Both subsets exhibited significant differences $(\mathrm{P}=0.027)$ between the children with RRIs and the controls. Thus, our data revealed a decrease in the percentage of mature/naive $\mathrm{B}$ cells $(76.8 \pm 10$ vs. $81.95 \pm 4, \mathrm{P}=0.027)$ and an increase in the percentage of memory $B$ cells $(23.2 \pm 10$ vs. $18.05 \pm 4, \mathrm{P}=0.027)$ in children with RRIs as compared to the control group (Fig. 5).

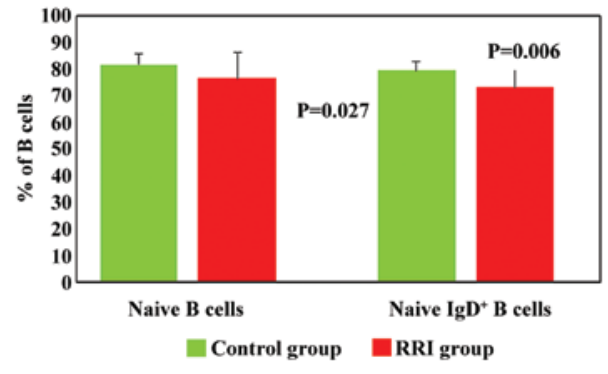

Figure 6. Distribution of naive $\mathrm{B}$ cells and naive $\mathrm{IgD}^{+} \mathrm{B}$ cells in peripheral blood. Naive $B$ cells and naive $\operatorname{IgD}^{+} B$ cells in the RRI group $(n=30)$ $(76.8 \pm 10, \mathrm{P}=0.027$ and $73.3 \pm 10, \mathrm{P}=0.006)$ and in the control group $(\mathrm{n}=10)$ $(81.95 \pm 4$ and $79.59 \pm 4)$. The results are presented as percentage from B cells $\left(\mathrm{LyCD} 19^{+} \mathrm{CD} 20^{+}\right)($means $\pm \mathrm{SD})$. RRI, respiratory recurrent infection.

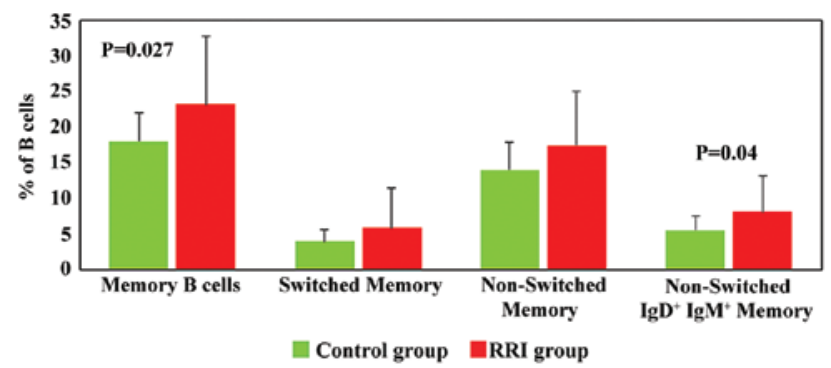

Figure 7. Distribution of memory B cells subsets in PB. Memory B cells, switched memory B cells, non-switched memory B cells and non-switched $\operatorname{IgD}^{+} \operatorname{IgM}{ }^{+}$memory B cells in RRI group $(n=30)(23.2 \pm 10, P=0.027,5.79 \pm 6$, $17.41 \pm 8$ and $8.07 \pm 5, \mathrm{P}=0.04)$ and in the control group $(\mathrm{n}=10)(18.05 \pm 4$ $3.97 \pm 2,14.09 \pm 4$ and $5.59 \pm 2$ ). The results are presented as percentage from B cells $\left(\mathrm{CD} 19^{+} \mathrm{CD} 20^{+}\right)$(means $\left.\pm \mathrm{SD}\right)$. RRI, respiratory recurrent infection.

Mature/naive B cells were analysed based on the expression of $\operatorname{IgD}$. In the children with RRIs, the numbers of naive $\operatorname{IgD}^{+} \mathrm{B}$ cells were significantly lower $(73.3 \pm 10, \mathrm{P}=0.006)$ than

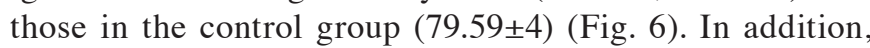
$61 \%$ of the children with RRIs exhibited low values for naive $\mathrm{IgD}^{+} \mathrm{B}$ cells (Table II). We hypothesised that the decrease in the numbers of total B lymphocytes was mainly due to the decrease in mature/naive $\operatorname{IgD} \mathrm{D}^{+} \mathrm{B}$ lymphocytes.

Memory B cells were analysed according to the expression of $\operatorname{IgD}$ and $\operatorname{IgM}$ and divided into switched memory B cells $\left(\operatorname{IgD}-\operatorname{Ig} M^{-}\right)$, non-switched memory B cells $\left(\operatorname{IgM} / \operatorname{IgD}^{+}\right)$and non-switched $\operatorname{IgD}^{+} \operatorname{IgM}^{+}$memory B cells (Fig. 7). The numbers 
of memory B cells were significantly increased in the RRI group (23. $2 \pm 10$ vs. $18.05 \pm 4$ in healthy children, $P=0.027$; Fig. 7$)$. All memory B cell subsets were increased in the children with RRIs; however, statistically significant differences between the RRI group and the control group were only observed for non-switched $\operatorname{IgD}^{+} \operatorname{IgM}{ }^{+}$memory B cells $(\mathrm{P}=0.04)$.

Plasmablasts/plasma cells represent the most mature subset of memory switched B cells. The values obtained for plasmablasts/plasma cells were very small and there are no differences between the 2 experimental groups $(2.61 \pm 2$ in RRI children, $2.99 \pm 2$ in the control group) (graph not shown).

In terms of overall B circulatory populations, in Table II, the incidence of peripheral deregulations is presented in the group of children with RRIs. The results revealed that a great majority of the children had decreased circulatory levels of B lymphocytes, this decrease being based on the actually mature B cells. The equilibrium is set by the fact that $50 \%$ of the children RRIs had high values of memory B cells.

\section{Discussion}

In this study, children with confirmed with respiratory infections with RSV were selected for the identification of circulatory cellular immune populations in order to depict an altered cellular immune response. In such cases, the investigation of immunological parameters, such as $\mathrm{T}$ and $\mathrm{B}$ cell subtypes may guide the treatment strategy.

The serum levels of immunoglobulins are generally considered to be an indicator of B cell functionality and the analysis of immunoglobulins is a screening test for the evaluation of the humoral immunity. In this study, serum immunoglobulin values in the children with RRIs tested were normal in $70 \%$ of cases and $30 \%$ of the cases exhibited decreases or increases in immunoglobulin levels. These tests did not suggest changes in order to justify the diagnosis of immunological recurrent infectious syndrome. Considering clinical syndrome in children with normal immunoglobulin values, it was necessary to complete the humoral investigation with cellular tests. In order to assess the immune cell status in children with RRIs, different subtypes of circulating $\mathrm{T}$ and $\mathrm{B}$ lymphocytes were analysed by flow cytometry, using two different custom panels: The $\mathrm{T}$ and NK-panel, to identify T-cell subsets and respectively NK cells, and B-panel for B-cell subsets.

The analysis of $\mathrm{T}$ cell subpopulations ( $\mathrm{T}$ and NK-panel) revealed a significant decrease in the $\mathrm{T}-\mathrm{CD} 8^{+}$lymphocytes percentages $(\mathrm{P}=0.009)$ in children with RRIs, while the percentages of $\mathrm{T}-\mathrm{CD}^{+}$and $\mathrm{T}-\mathrm{CD} 4^{+}$lymphocytes were comparable in both experimental groups (patients and control group). Most of the children with RRIs exhibited changes in the relative number of $\mathrm{T}$ lymphocytes. Thus, a significant number of children $(67 \%)$ exhibited decreases in the numbers of T-CD8 ${ }^{+}$ lymphocytes; $47 \%$ of cases presented an increased value for T-CD4 ${ }^{+}$lymphocytes, and $40 \%$ of children with RRIs presented a decreased percentage of total $\mathrm{T}-\mathrm{CD}^{+}$lymphocytes (Table I). Taking into account that $\mathrm{T}-\mathrm{CD} 8^{+}$lymphocytes are involved in antiviral immune response, it can be presumed that there is a decrease in the antiviral response in RRI children proven by the reduced $\mathrm{T}-\mathrm{CD} 8^{+}$mean values. In addition, there was also an increase in $\mathrm{T}-\mathrm{CD} 4^{+}$mean values as compared to the control group, with no statistical significance, which suggests the stimulation of this lymphocyte subpopulation during viral respiratory infections.

The $\mathrm{T}-\mathrm{CD} 4^{+} / \mathrm{T}-\mathrm{CD} 8^{+}$ratio was significantly higher in the RRI group as compared to the control group $(\mathrm{P}=0.002)$. A significant number of RRI children $(63 \%)$ exhibited an increased value for the $\mathrm{T}-\mathrm{CD} 4^{+} / \mathrm{T}-\mathrm{CD} 8^{+}$ratio (Table I). Increased values of the $\mathrm{T}-\mathrm{CD} 4^{+} / \mathrm{T}-\mathrm{CD} 8^{+}$ratio are explained by the values obtained for each cell subpopulation (high values for $\mathrm{T}^{-\mathrm{CD}} 4^{+}$in $47 \%$ of cases, low values for $\mathrm{T}-\mathrm{CD}^{+}$in $67 \%$ of cases). This increased ratio reveals the tendency of the cellular immune response to immuno-stimulation due to the presence of infectious syndrome. Immuno-stimulation is supported by the $\mathrm{T}-\mathrm{CD} 4^{+}$subpopulation even in the case where $\mathrm{T}-\mathrm{CD} 8^{+}$is diminished.

T-DN lymphocytes are probably derived either from double-positive T-immature cells $\left(\mathrm{CD}^{+} \mathrm{CD}^{+}\right)$or mono-positive $\left(\mathrm{CD}^{+}{ }^{+} \mathrm{CD} 8^{-}, \mathrm{CD}^{-} \mathrm{CD}^{+}\right)(13)$ and it has been shown that substantial proportion of T-DN appears in the inflammatory response to syncytial virus infection (11). These cells appear to be involved in inflammation and autoimmune diseases having a regulatory character (12), while their participation in infectious syndromes has not yet been clarified. T-DN cells could represent a complementary functional reserve for T-lymphocytes under conditions of a decrease in the $\mathrm{T}-\mathrm{CD} 4^{+}$subpopulation in cellular ID or HIV infection (13). In this study, the values obtained for T-DN for both experimental groups were within normal limits, and only $23 \%$ of RRI children had an increased value $(>10)$. The increase in T-DN did not occur in a significant number of children with RRIs, but only in $23 \%$ (Table I). This was probably due to the fact that there were few cases where the 'back-up' role of T-DN was needed, namely in the cases presenting with low values of $\mathrm{T}^{-\mathrm{CD}} 4^{+}$cells. The 'reservoir' T-DN role was met in only 2 cases with low $\mathrm{T}-\mathrm{CD} 4^{+}$numbers, and cannot be considered a rule in this pathology. The mean values obtained for T-DN cells in both experimental groups were similar.

The T and NK-panel was also used to quantify the NK and NKT cells. While NKT cell analysis revealed very low values for both experimental groups, for NK cells, the obtained values differed significantly $(\mathrm{P}=0.003)$ in the RRI group as compared to healthy children. Although the NK cell values were significantly higher in the RRI group as compared to healthy children, and $57 \%$ of RRI children exhibited increases, these values were within the normal range for NK cells. We could not rule out the possibility that by increasing the number of infected children, the standard deviation of the mean would not decrease and hence, the difference between the controls and ill children would become significantly different. Although NK cells are involved in the antiviral response, there are no peripheral NK cell changes in the RRI group, indicating that this population remains within the normal established ranges and sustains the antiviral defence.

In addition, peripheral blood B cell subsets, including total B cells, mature/naive B cells, memory B cells, switched memory B cells $\operatorname{IgD}^{-} \operatorname{IgM}^{-}$, non-switched memory B cells $\operatorname{IgM} / \operatorname{IgD}^{+}$, non-switched $\operatorname{IgD}^{+} \operatorname{IgM}^{+}$memory B cells and plasmablasts/plasma cells were evaluated for RRI children and the obtained data were compared with control group children. For the $\mathrm{B}$ panel, the main change observed was the decrease in the total B cell population percentages in most of the children with 
RRIs (86\%). The mean values of total B cells were also significant lower in the children with RRIs $\left(\mathrm{P}=4.5 \times 10^{-5}\right)$ as compared to the control group. Based on CD27 expression, the PB total B lymphocytes were divided into 2 subsets: Mature/naive $\mathrm{B}$ cells $\left(\mathrm{CD} 27^{-}\right)$and memory B cells $\left(\mathrm{CD} 27^{+}\right)$. In this study, both subsets differed significantly $(\mathrm{P}=0.027)$ between the children with RRIs compared to the controls. Thus, our data revealed a decrease in the percentage of mature/naive $B$ cells $(\mathrm{P}=0.027)$ and an increase in the percentage of memory $B$ cells $(\mathrm{P}=0.027)$ in children with RRIs as compared to the control group. Mature/naive B cells were analysed based on the expression of IgD. In the children with RRIs, the numbers of naive $\operatorname{IgD}^{+} \mathrm{B}$ cells were significantly lower $(\mathrm{P}=0.006)$ than in those in the control group. In addition, $61 \%$ of the children with RRIs exhibited low values for naive $\operatorname{IgD}^{+} \mathrm{B}$ cells We hypothesised that the decrease in the numbers of total B lymphocytes was mainly due to the decrease in mature/naive $\mathrm{IgD}^{+} \mathrm{B}$ lymphocytes.

Memory B cells were analysed according to the expression of $\operatorname{IgD}$ and $\operatorname{IgM}$ and divided into switched memory B cells $\left(\operatorname{IgD}-\operatorname{IgM}^{-}\right)$, non-switched memory $B$ cells $\left(\operatorname{IgM} / \operatorname{IgD}^{+}\right)$and non-switched $\operatorname{IgD}^{+} \operatorname{IgM}{ }^{+}$memory B cells. These cells respond to the thymus-dependent antigens and will generate long-term immunological memory. These lymphocytes will circulate in the peripheral blood regardless of the antigenic stimulation. In the moment the cells meet their specific antigen, they will proliferate and differentiate in plasma cells and will secrete high affinity antibodies (IgG). In this study, memory B cells were significantly increased in the RRI group $(\mathrm{P}=0.027)$. This finding is somewhat to be expected as the virus is not at the first encounter with the immune system of the children. All memory B cell subsets were increased in children with RRIs; however, the results were statistically significant $(\mathrm{P}=0.04)$ only for the non-switched $\operatorname{IgD}^{+} \operatorname{IgM}^{+}$memory $\mathrm{B}$ cells between the RRI group and the controls. This can be explained by the mobilization in peripheral circulation of memory $B$ cells during infection, with the predominance of the non-switched $\mathrm{B}$ cells, mainly non-switched $\mathrm{IgD}^{+} \operatorname{IgM}^{+}$memory $\mathrm{B}$ cells $(\mathrm{P}=0.04)$.

Plasmablasts/plasma cells represent the most mature subset of memory switched B cells. The values obtained for this subset were very small and there were no differences between the RRI group and the controls. This finding is yet again to be expected as the immunoglobulins levels are in normal ranges.

There are various reported results in children infected with syncytial virus. While some reports have shown a Th2 predominance in serum (14-16), others have shown a decrease in the Th1 response (17). These results in fact indicate that the Th1/Th2 balance is not a golden standard for this infection in children $(18,19)$ and that there are several immune populations involved (20). The findings of this study demonstrated that, indeed, a decrease in the $\mathrm{T}-\mathrm{CD} 8^{+}$and total $\mathrm{B}$ cells percentages was balanced by an increase in circulating memory B cells. The decrease in total $\mathrm{B}$ cells was mainly due to the decrease in naive $\operatorname{IgD}^{+} \mathrm{B}$ cells.

Throughout life, the immune system also evolves. Human respiratory syncytial virus infections are responsible worldwide for bronchiolitis, pneumonia and asthma, particularly in children. Therefore, $70 \%$ of children will have been infected in their first 12 months of life, and at 24 months, all children will have been infected with this virus (21). Mild upper respiratory tract symptomatology will be triggered, and around $3 \%$ will be rushed to the ICU, where the mortality rate can reach up to $10 \%(22,23)$. As this poses a serious health concern among small children (24), immunological parameters to follow this type of infection in children and extended immunophenotyping with the investigation of immunological parameters, such as $\mathrm{T}$ and $\mathrm{B}$ cell subtypes, are mandatory (25).

In this study, we investigated several immune parameters in a group of children with RRIs positive for RSV in order to identify the immunological changes that could lead to this clinical syndrome. We did not find alterations regarding the serum levels of $\operatorname{IgG}, \operatorname{Ig} \mathrm{A}, \operatorname{IgM}$, thus taking into account that these are actually the routine tests carried out in clinical practice; the results were not sufficient for an immunodiagnosis, and thus, we considered that a cellular investigation is also necessary. We performed several cellular assays regarding peripheral T, B, NK cells, as well as several subtypes of these cells that are not currently performed, such as T-DN cells, NKT cells, mature/naive B cells, memory B cells and plasma cells. As the circulatory immunoglobulin level was in the normal range, the peripheral blood immune cells exhibited specific deregulations. Hence, a decrease in the circulatory $\mathrm{T}-\mathrm{CD}^{+}$and total $\mathrm{B}$ cells percentages and an increase in memory B cells was observed. The decrease in total B cells was mainly due to the decrease in naive $\operatorname{IgD}^{+} \mathrm{B}$ cells. It can thus be concluded that in respiratory recurrent infections, the investigation of immunological parameters, such as $\mathrm{T}$ and $\mathrm{B}$ cell subtypes could complete the clinical diagnosis and may guide the treatment, thus increasing the quality of life of the patients.

\section{Acknowledgements}

The present study will be integrated in the original part of the $\mathrm{PhD}$ thesis of first author and PhD student ANM.

\section{Funding}

This study was supported by the Core Program, implemented with the support of NASR, projects PN 19.29.01.01; PN19.29.02.03, Grant PN-III-P1-1.2-PCCDI-2017-0341/2018 and $7 \mathrm{PFE} / 16.102018$.

\section{Availability of data and materials}

The datasets used and/or analysed during the present study are available from the corresponding author on reasonable request.

\section{Authors' contributions}

ANM, MS, RIH, GI, CConstantin, IRP and CUrsaciuc were responsible for the research creation and design, data acquisition, analysis and interpretation of the data, statistical analysis, manuscript drafting, and the critical revision of the manuscript for important intellectual content. ANM, MS, IRP, CChifiriuc, CUlmeanu and $\mathrm{MN}$ were responsible for the interpretation of the data, manuscript drafting, and the critical revision of the manuscript for important intellectual content. All authors have read and approved the final manuscript. 


\section{Ethics approval and consent to participate}

For all patients and the control group, an informed consent was signed from each subject's legally authorized representative. The study was approved by the Ethics Committee from Victor Babes National Institute (no. 17/17.05.2016).

\section{Patient consent for publication}

Not applicable.

\section{Competing interests}

The authors declare that they have no competing interests.

\section{References}

1. Gervassi AL and Horton H: Is infant immunity actively suppressed or immature? Virology (Auckl) 2014: 1-9, 2014.

2. Maddux AB and Douglas IS: Is the developmentally immature immune response in paediatric sepsis a recapitulation of immune tolerance? Immunology 145: 1-10, 2015.

3. Feleszko W, Ruszczyński M and Zalewski BM: Non-specific immune stimulation in respiratory tract infections. Separating the wheat from the chaff. Paediatr Respir Rev 15: 200-206, 2014

4. McCusker C and Warrington R: Primary immunodeficiency. Allergy Asthma Clin Immunol 7 (Suppl 1): S11, 2011.

5. Alkhater SA: Approach to the child with recurrent infections. J Family Community Med 16: 77-82, 2009.

6. El-Azami-El-Idrissi M, Lakhdar-Idrissi M, Chaouki S, Atmani S, Bouharrou A and Hida M: Pediatric recurrent respiratory tract infections: When and how to explore the immune system? (About 53 cases). Pan Afr Med J 24: 53, 2016.

7. Mammas IN, Koutsaftiki C, Nika E, Vagia F, Zaravinos A, Priftis KN, Voyatzi A, Theodoridou M, Myriokefalitakis N and Spandidos DA: Detection of human metapneumovirus in infants with acute respiratory tract infection. Mol Med Rep 4: 267-271, 2011.

8. American Academy of Pediatrics Committee on Environmental Health: Environmental tobacco smoke: A hazard to children. Pediatrics 99: 639-642, 1997.

9. Grüber C, Keil T, Kulig M, Roll S, Wahn U and Wahn V; MAS-90 Study Group: History of respiratory infections in the first $12 \mathrm{yr}$ among children from a birth cohort. Pediatr Allergy Immunol 19: 505-512, 2008

10. Erkeller-Yuksel FM, Deneys V, Yuksel B, Hannet I, Hulstaert F, Hamilton C, Mackinnon H, Stokes LT, Munhyeshuli V, Vanlangendonck F, et al: Age-related changes in human blood lymphocyte subpopulations. J Pediatr 120: 216-222, 1992.

11. Johnson JE, Gonzales RA, Olson SJ, Wright PF and Graham BS: The histopathology of fatal untreated human respiratory syncytial virus infection. Mod Pathol 20: 108-119, 2007.

12. Hillhouse EE and Lesage S: A comprehensive review of the phenotype and function of antigen-specific immunoregulatory double negative T cells. J Autoimmun 40: 58-65, 2013.
13. Sundaravaradan V, Mir KD and Sodora DL: Double-negative T cells during HIV/SIV infections: Potential pinch hitters in the T-cell lineup. Curr Opin HIV AIDS 7: 164-171, 2012.

14. Hassan MA, Eldin AME and Ahmed MM: T-helper2/T-helper1 imbalance in respiratory syncytial virus bronchiolitis in relation to disease severity and outcome. Egypt J Immunol 15: 153-160, 2008.

15. Qin L, Peng D, Hu C, Xiang Y, Zhou Y, Tan Y and Qin X: Differentiation of Th subsets inhibited by nonstructural proteins of respiratory syncytial virus is mediated by ubiquitination. PLoS One 9: e101469, 2014.

16. Dulek DE, Newcomb DC, Toki S, Goliniewska K, Cephus J, Reiss S, Bates JT, Crowe JE Jr, Boyd KL, Moore ML, et al: STAT4 deficiency fails to induce lung Th2 or Th17 immunity following primary or secondary respiratory syncytial virus (RSV) challenge but enhances the lung RSV-specific CD8+ $\mathrm{T}$ cell immune response to secondary challenge. J Virol 88: 9655-9672, 2014.

17. Legg JP, Hussain IR, Warner JA, Johnston SL and Warner JO: Type 1 and type 2 cytokine imbalance in acute respiratory syncytial virus bronchiolitis. Am J Respir Crit Care Med 168: 633-639, 2003.

18. Pinto RA, Arredondo SM, Bono MR, Gaggero AA and Díaz PV: T helper $1 / T$ helper 2 cytokine imbalance in respiratory syncytial virus infection is associated with increased endogenous plasma cortisol. Pediatrics 117: e878-e886, 2006.

19. van Benten IJ, van Drunen CM, Koopman LP, KleinJan A, van Middelkoop BC, de Waal L, Osterhaus AD, Neijens HJ and Fokkens WJ: RSV-induced bronchiolitis but not upper respiratory tract infection is accompanied by an increased nasal IL-18 response. J Med Virol 71: 290-297, 2003.

20. Mangodt TC, Van Herck MA, Nullens S, Ramet J, De Dooy JJ, Jorens PG and De Winter BY: The role of Th17 and Treg responses in the pathogenesis of RSV infection. Pediatr Res 78: 483-491, 2015.

21. Bueno SM, González PA, Pacheco R, Leiva ED, Cautivo KM, Tobar HE, Mora JE, Prado CE, Zúñiga JP, Jiménez J, et al: Host immunity during RSV pathogenesis. Int Immunopharmacol 8: 1320-1329, 2008

22. McNamara PS and Smyth RL: The pathogenesis of respiratory syncytial virus disease in childhood. Br Med Bull 61: 13-28, 2002.

23. Hervás D, Reina J, Yañez A, del Valle JM, Figuerola J and Hervás JA: Epidemiology of hospitalization for acute bronchiolitis in children: Differences between RSV and non-RSV bronchiolitis. Eur J Clin Microbiol Infect Dis 31: 1975-1981, 2012.

24. Mammas IN, Greenough A, Theodoridou M, Kramvis A, Rusan M, Melidou A, Korovessi P, Papaioannou G, Papatheodoropoulou A, Koutsaftiki C, et al: Paediatric Virology and its interaction between basic science and clinical practice (Review). Int J Mol Med 41: 1165-1176, 2018.

25. Munteanu A, Surcel M, Constantin C and Neagu M: Respiratory infection with syncitial virus in children - immunologicalhighlights. Rev Biol Biomed Sci (In Press).

This work is licensed under a Creative Commons Attribution-NonCommercial-NoDerivatives 4.0 International (CC BY-NC-ND 4.0) License. 